\title{
Mitigate Grain Arsenic Load of Summer Rice through Water Management
}

\author{
M.D. Bairagya ${ }^{1 *}$, C.K. Kundu ${ }^{1}$ and S. Sarkar ${ }^{2}$ \\ ${ }^{1}$ Department of Agronomy, ${ }^{2}$ Department of Agro Meteorology, Faculty of Agriculture, Bidhan \\ Chandra Krishi Viswavidyalaya, Kalyani, Nadia, West Bengal, India \\ *Corresponding author
}

\section{Keywords}

Rice, Irrigation regimes, Arsenic

\section{Article Info}

Accepted: 04 May 2018 Available Online: 10 June 2018

\section{A B S T R A C T}

High yield potentiality of summer rice motivates farmers in West Bengal to grow rice even in summer season. Summer rice receives few fold higher irrigation over other aerable crops. Farmers of this area irrigate 1300-1400 mm water for summer rice. In Nadia district of West-Bengal during summer season, the main source of irrigation water is ground water which contains high amount $\left(0.098-0.345 \mathrm{mgL}^{-1}\right)$ of arsenic which is responsible for higher arsenic concentration in grain and straw. A field experiment was carried out during February to May, 2014 with six irrigation regimes. The irrigation regimes were $\mathrm{I}_{1^{-}}$ Continuous ponding, $\mathrm{I}_{2}$ - Intermittent ponding, where irrigation was given two days after disappearance of ponded water, $\mathrm{I}_{3}$ - Intermittent ponding, irrigation was given four days after disappearance of ponded water, $\mathrm{I}_{4}$ - Saturation with SRI transplanting, $\mathrm{I}_{5}$ - Intermittent ponding, irrigation was given two days after disappearance of ponded water, $\mathrm{I}_{6}$ - Raised and sunken bed in a ratio of $1: 2$. Soil water stress in $I_{2}$ and $I_{4}$ were imposed during 15 to 40 days after transplanting, However, in case of $\mathrm{I}_{5}$ stress imposition stage was 65 to 80 DAT. Rest period for I2, I3, I4 and $\mathrm{I}_{5}$ regime field was kept under continuous ponding situation. Results showed that the grain $\left(0.52 \mathrm{mgkg}^{-1}\right)$ and straw $\left(3.05 \mathrm{mgkg}^{-1}\right)$ arsenic content were significantly less in $\mathrm{I}_{4}$ where $(36.4 \%)$ less water was irrigate over $\mathrm{I}_{1}$. No significant yield reduction was found under $I_{4}\left(6.47 \mathrm{Mg} \mathrm{ha}^{-1}\right)$ as compare to $I_{1}\left(6.64 \mathrm{Mg} \mathrm{ha}^{-1}\right)$. Application of $100 \mathrm{~mm}$ and $380 \mathrm{~mm}$ less water respectively under $I_{5}$ and $I_{6}$ showed decrease in grain arsenic content by $36.7 \%$ and $26.6 \%$ respectively. Raise and sunken bed can effectively decrease grain arsenic content. But all three regimes significantly decrease grain yield. To reduce arsenic content in rice grain and straw without affecting yield, the field should be kept saturated during 15-40 days after transplanting.

\section{Introduction}

Rice is a staple food in South East Asia. Worldwide, about 79 million ha of irrigated lowlands provide $75 \%$ of the total world's rice production (Maclean et al., 2002). Higher grain yield and monetary return motivates the farmers of Bengal delta to grow rice in dry (January to May) season popularly known as summer rice. At the field level, rice receives up to two to three folds more water than other irrigated crops (Tuong et al., 2005). Cultivate one hectare of rice in summer season on an average, 1200 to 1300 cubic meter of water is 
required. On an average, 34-43\% of the world irrigation water is used to irrigate rice (Bouman et al., 2006). Besides, water is becoming increasingly scarce and grave concerns exist about the sustainability of irrigated agriculture (Rijsberman, 2006). In West Bengal, in spite of ground water depletion, farmers are growing boro rice covering more than 1.4 mha. Not only the scarcity of ground water but also arsenic concentration in remaining ground water of the vast area is above the critical level as determined by WHO $(0.05 \mathrm{mg} / \mathrm{l})$. This high concentration of arsenic present in ground water causes cancer and other severe diseases, which is threatening to human health. It is suspected that the STW irrigation water may also have a high As content which may increase the As level in the soils, and thus, high amounts of As may accumulate in food grains creating an additional health hazard.

Rapid adsorption of As from irrigation water to soil may explain the spatial patterns found in irrigation canals and some paddy fields (Farid et al., 2005). When the amount of arsenic in the groundwater is high, it has been observed that the levels of arsenic in agricultural land soil and plants are correspondingly high (Roychowdhury et al., 2008). High As concentrations in irrigationwater can lead to elevated concentrations of As in soil and subsequently in rice grain and straw (Duxbury et al., 2003; Williams et al., 2006). Very high levels of Arsenic accumulation in rice straw indicates that consumption of such contaminated straw by cattle which could be a direct threat for their health and also, indirectly, to human via presumably contaminated bovine meat and milk (Abedin et al., 2002). To decrease the rice grain and straw arsenic load it is an important target to reduce potential water use (Wang et al., 2002). Water saving irrigation technology based on the concept of alternate wetting and drying have been shown to save water (Bouman and Tuong, 2001; Belder et al., 2004). Another one of the major water saving technology developing is continuous soil saturation (Borell et al., 1997). Deficiency of water during vegetative stage shows insignificant effect on grain yield (Yambo and Ingram, 1988). A farmer's field study was conducted to (i) find out the level of arsenic accumulation by rice grain and straw with irrigation water contaminated with arsenic and (ii) to mitigate grain arsenic content through water management without affecting yield.

\section{Materials and Methods}

\section{Selection of study area}

The experiment was conducted at Ghentugachi village of Nadia district in West Bengal, India $\left(23^{\circ} 02^{\prime \prime} \mathrm{N}\right.$, longitude $88^{\circ} 35^{\prime \prime} \mathrm{E}$; altitude of $8.8 \mathrm{~m}$ amsl) during summer season 2014. The soil type of experimental field was silty loam with $\mathrm{pH}$ value of 7.22. The basic properties of the soil are presented in Table 1.

\section{Details about experiment}

Six irrigation management treatments were tested in randomized block design (RBD) with four replications. The treatments consisted of $\mathrm{T}_{1}$ - Continuous ponding (spacing $15 \times 15 \mathrm{~cm}$ ), $\mathrm{T}_{2}$ - Intermittent ponding 15- $40 \mathrm{DAT}, 2$ days after disappearance (spacing $15 \times 15 \mathrm{~cm}$ ), $\mathrm{T}_{3}$ Intermittent ponding 15- 40 DAT, 4 days after disappearance (spacing $15 \times 15 \mathrm{~cm}$ ), $\mathrm{T}_{4^{-}}$ Continuous soil saturation (SRI, spacing 20 $\times 20 \mathrm{~cm}), \mathrm{T}_{5^{-}}$Intermittent ponding 15- 40 DAT, 2 days after disappearance (spacing 15 $\times 15 \mathrm{~cm})$ and 65 DAT to last irrigation, $\mathrm{T}_{6^{-}}$ Raised and sunken bed in a ratio of 1:2. The plot size was $9 \mathrm{~m} \times 5 \mathrm{~m}$. Thirty eight days old Shatabdi (IET 4786) rice seedling was sown on $04 / 02 / 2011\left(^{\text {th }}\right.$ standard week). Total fertilizers were applied at a rate of $100 \mathrm{~kg} \mathrm{~N}$ $\mathrm{ha}^{-1}, 60 \mathrm{~kg} \mathrm{P}_{2} \mathrm{O}_{5} \mathrm{ha}^{-1}$ and $60 \mathrm{~kg} \mathrm{~K}_{2} \mathrm{O} \mathrm{ha}{ }^{-1}$. The crop was harvested on 05/05/2014. 


\section{Statistical analysis}

Differences among irrigation regimes on rice yield (grain and straw) were tested with Fisher's least significant difference $(\mathrm{P} \leq 0.05)$ test using analysis of variance as mentioned in Panse and Sukhatme (1967). The statistical measurements of coefficient of determination $\left(R^{2}\right)$ of the equations were calculated to assess the degree of association between two variables.

\section{Calculations}

The depth of irrigation for intermittent ponding was calculated by following the relationship proposed by Chaudhary (1997):

$D_{i}=\left(\Theta_{s}-\Theta_{i}\right) D_{r}+D_{s}$

Where $D_{i}$ is the depth of irrigation water to be applied $(\mathrm{mm}) ; \mathrm{D}_{\mathrm{r}}$ is the depth of root zone $(\mathrm{mm}) ; \mathrm{D}_{\mathrm{s}}$ is the depth of submergence required $(\mathrm{mm})$ in the present study $\mathrm{D}_{\mathrm{s}}$ value was 50 $\mathrm{mm}$; $\Theta_{\mathrm{s}}$ is the average volumetric moisture content $\left(\mathrm{m}^{3} \mathrm{~m}^{-3}\right)$ of the root zone at saturation and $\Theta_{\mathrm{i}}$ is the average volumetric soil water content $\left(\mathrm{m}^{3} \mathrm{~m}^{-3}\right)$ at the time of irrigation water application. Both $\Theta_{\mathrm{s}}$ and $\Theta_{\mathrm{i}}$ are expressed as fractions. The term $\left(\Theta_{\mathrm{s}}-\Theta_{\mathrm{i}}\right)$ gives the volume of water required to raise the water content of a unit volume of soil to saturation.

\section{Analysis of arsenic}

\section{Total arsenic}

Total arsenic was analyzed in all samples by wet ashing procedure in hot plate using triacid mixture of nitric acid perchloric acid and sulphuric acid at 10:4:1 ratio following the method modified by Datta et al., (2010) and Datta et al., (2011) and properly digested sample were diluted with Millipore water, passed through filter paper and made the volume $10 \mathrm{ml}$ with concentrated hydrochloric acid $(5 \mathrm{ml})$ was added to it and shaken well then $1 \mathrm{ml}$ mixture of potassium iodide (5\%) and ascorbic acid (5\%) mixture was added and kept the aliquot for 45 min for transformation of arsenate to arsenite (Haring et al., 1982). Final volume was made up to $50 \mathrm{ml}$ with Millipore water for reading in atomic absorption spectrophotometer (FI-HG-AAS, Perkin Elmer Aanalyst 400) using external calibration through arsenic as standard. For each sample three replicates were taken and the mean values were obtained on the basis of calculation of those three replicates.

\section{Results and Discussion}

The highest amount of irrigation water applied in $\mathrm{I}_{1}(1100 \mathrm{~mm})$ showed highest amount of arsenic in soil $\left(15.7 \mathrm{mg} \mathrm{kg}^{-1}\right)$, straw $(3.63 \mathrm{mg}$ $\left.\mathrm{kg}^{-1}\right)$ as well as grain $\left(0.79 \mathrm{mg} \mathrm{kg}^{-1}\right)$. On the other hand, in $\mathrm{I}_{4}$, where least amount of irrigation water applied $(700 \mathrm{~mm})$ found least concentration of soil arsenic (14.6 mg kg-1). The rice grain arsenic content found lowest in $\mathrm{I}_{5}\left(0.5 \mathrm{mg} \mathrm{kg}^{-1}\right)$ with the grain yield $(6.54 \mathrm{t}$ $\left.\mathrm{ha}^{-1}\right)$ produced is at per with $\mathrm{I}_{1}\left(6.64 \mathrm{tha}^{-1}\right)$.

Through water management the grain arsenic concentration in continuous soil saturation can be reduced upto $34.2 \%$ in Shatabdi (IET 4786) rice variety with the saving of water is around $36.4 \%$ and there is no significant yield difference.

After harvesting of the rice crop in case of continuous soil saturation the soil arsenic content increase at rate of $3.55 \%$ but in case of continuous ponding the increase rate is $11.35 \%$.

Arsenic concentrations in rice roots, straw and grain increased significantly $(P<0.001)$ with increasing arsenic content in irrigation water. Regardless of irrigation water arsenic concentration, rice tissue arsenic concentration followed the trend: root > straw > grain (Fig. 1 and 2; Table 2). 
Fig.1 The relationship between the amounts of arsenic accumulated by rice grain and straw and arsenic added through irrigation water

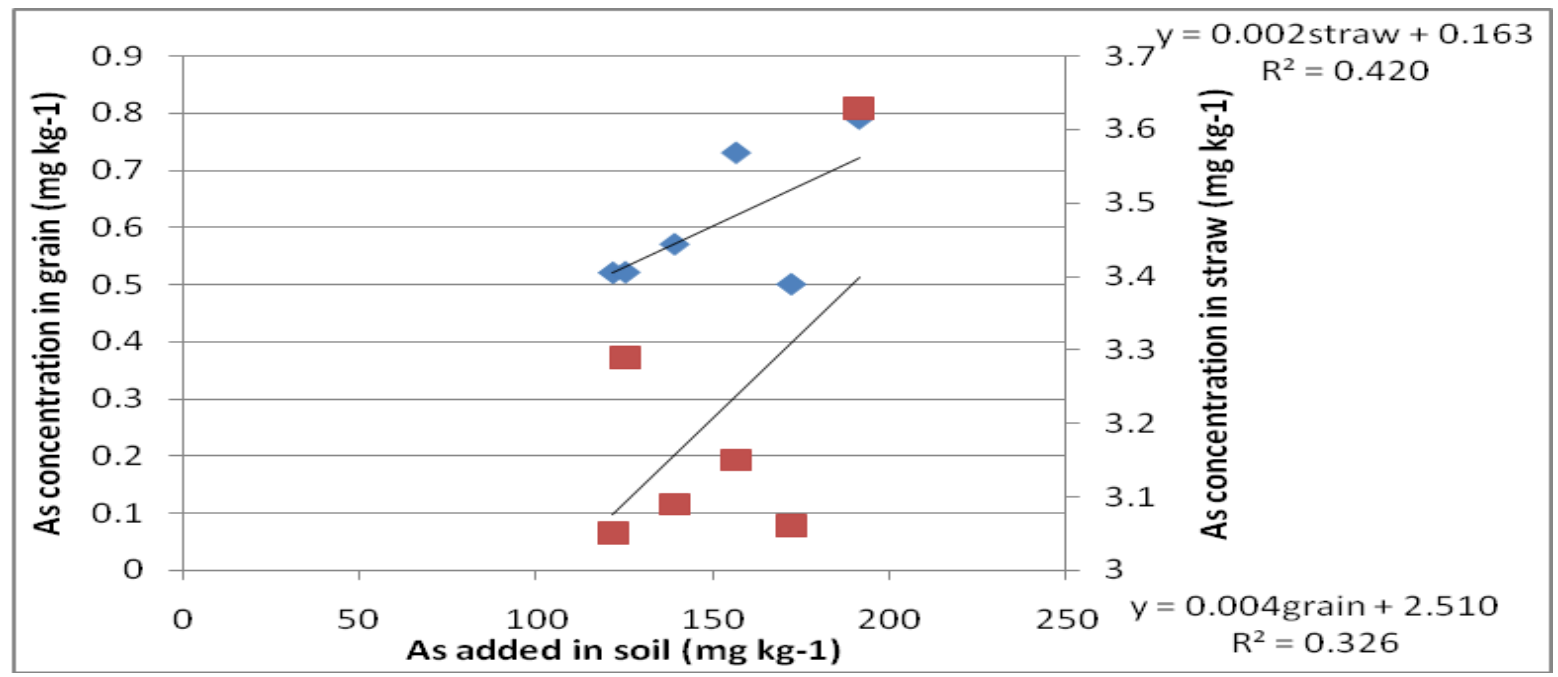

Fig.2 Relationship between soil arsenic and arsenic content in rice grain

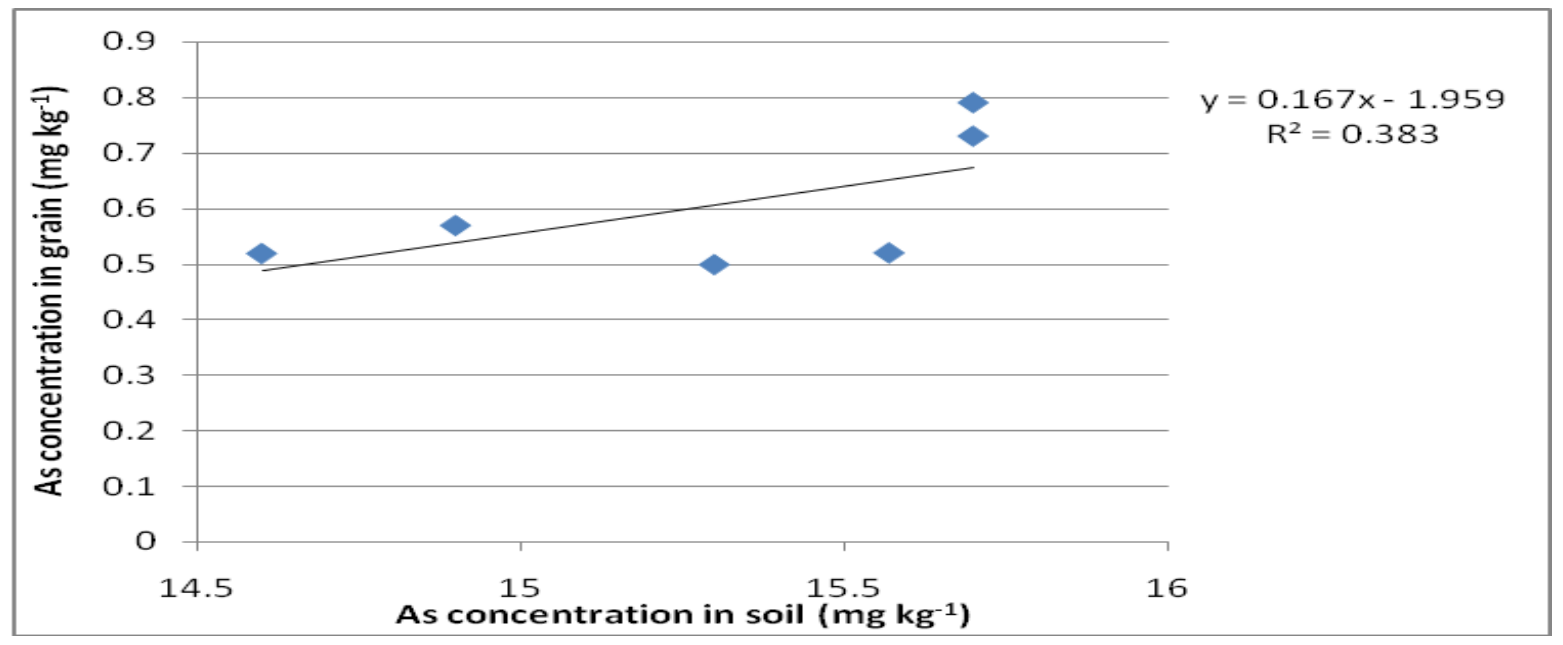

Table.1 Important physicochemical properties of the experimental soil

\begin{tabular}{|l|c|}
\hline \multicolumn{1}{|c|}{ Physicochemical properties } & Value \\
\hline Sand & 41.8 \\
\hline Silt & 41.5 \\
\hline Clay & 16.7 \\
\hline pH & 7.22 \\
\hline Electrical conductivity & $1.18 \mathrm{ds} \mathrm{m}-1$ \\
\hline Organic carbon & $9.90 \mathrm{~g} \mathrm{~kg}-1$ \\
\hline A vailable nitrogen & $152.52 \mathrm{~kg} \mathrm{ha}-1$ \\
\hline Available phosphorus & $65.7 \mathrm{~kg} \mathrm{ha}-1$ \\
\hline A vailable potassium & $135.5 \mathrm{~kg} \mathrm{ha}-1$ \\
\hline
\end{tabular}


Table.2 Effect of irrigation regimes on arsenic concentration of rice grain and straw with rice grain and straw yield

\begin{tabular}{|c|c|c|c|c|c|c|c|}
\hline \multirow{2}{*}{$\begin{array}{l}\text { Irrigation } \\
\text { Regime }\end{array}$} & \multirow{2}{*}{$\begin{array}{l}\text { Water } \\
\text { irrigated } \\
(\mathrm{mm})\end{array}$} & \multirow{2}{*}{$\begin{array}{l}\text { As added, mg } \\
\text { m }^{-2} \text { soil through } \\
\text { irrigation water }\end{array}$} & \multicolumn{3}{|c|}{ As concentration ( $\mathrm{mg} \mathrm{kg}^{-1}$ ) } & \multirow{2}{*}{$\begin{array}{l}\text { Grain } \\
\text { yield, } \\
\text { Mg ha }^{-1}\end{array}$} & \multirow{2}{*}{$\begin{array}{l}\text { Straw } \\
\text { yield, } \\
\text { Mg ha }^{-1}\end{array}$} \\
\hline & & & soil & grain & straw & & \\
\hline $\mathbf{I}_{1}$ & 1100 & 191.4 & 15.70 & 0.79 & 3.63 & 6.64 & 9.05 \\
\hline $\mathrm{I}_{2}$ & 900 & 156.6 & 15.70 & 0.73 & 3.15 & 6.52 & 9.14 \\
\hline $\mathbf{I}_{3}$ & 800 & 139.2 & 14.90 & 0.57 & 3.09 & 5.74 & 8.55 \\
\hline $\mathbf{I}_{4}$ & 700 & 121.8 & 14.60 & 0.52 & 3.05 & 6.50 & 10.30 \\
\hline $\mathbf{I}_{5}$ & 1000 & 172.2 & 15.30 & 0.5 & 3.06 & 6.54 & 9.21 \\
\hline $\mathrm{I}_{6}$ & 720 & 125.3 & 15.57 & 0.521 & 3.29 & 6.25 & 8.06 \\
\hline $\begin{array}{l}\text { LSD } \\
(p=0.05)\end{array}$ & & 37.6 & 0.82 & 0.075 & 0.18 & 0.165 & 0.32 \\
\hline
\end{tabular}

Imposition of saturation during vegetative stage caused insignificant changes in grain yield with significant reduction in arsenic concentration in rice grain

\section{Acknowledgement}

We are grateful to the NAIP, COMP-4 (ICAR) for providing financial support to carry out the research.

\section{References}

Belder, P., Bouman, B. A. M., Spiertz, J. H. J., Cabangon, R., Lu G., Quilang, E. J. P., Li, Y. and Tuong, T. P. (2004). Effect of water-saving irrigation on rice yield and water use in typical lowland conditions in Asia. Agric. Water Manage. 65, 193-210.

Borell, A., Garside, A., and Fukai, S. (1997). Improving eYciency of water for irrigated rice in a semi- arid tropical environment. Field Crops Res. 52, 231248.

Bouman, B. A. M. and Tuong, T. P. (2001). Field water management to save water and increase its productivity in irrigated rice. Agric. Water Manage. 49, 11-30.
Bouman, B. A. M., Humphreys, E., Barker, R., and Tuong, T. P. (2006). Rice water. Adv. Agron. 92, 187-237.

Bouman, B. A. M., Lampayan, R. M. and Tuong, T. P. (2007). Water Management in Irrigated Rice: Coping with Water Scarcity. IRRI. Los Banos, Philippines.

Duxbury J. M., Mayer A. B., Lauren J. G. and Hassan N. (2003). Food chain aspects of arsenic contamination in Bangladesh: Effects on quality and productivity of rice. J Environ Sci Health 38:61-69. doi:10.1081/ESE-120016881

Maclean, J. L., Dawe, D., Hardy, B., and Hettel, G. P. (Eds.) (2002). "Rice Almanac,' p. 253. International Rice Research Institute, Los $\mathrm{Ban}^{\sim}$ os, Philippines.

Rijsberman, F. R. (2006). Water scarcity: Fact or fiction? Agric. Water Manage. 80, 522.

Roychowdhury, T., Uchino, T. and Tokunaga H. (2008). Effect of arsenic on soil, plant and foodstuffs by using irrigated groundwater and pond water from Nadia district, West Bengal. International Journal of Environment and Pollution. 33, 2/3 218 - 234. 
Stoop, W. A., Adam, A. and Kassam, A. (2009). Comparing rice production systems: A challenge for agronomic research and for the dissemination of knowledge-intensive farming practices. Agricultural Water Management 96: 1491-1501.

Tuong, T. P., Bouman, B. A. M. and Mortimer, M. (2005). More rice, less water-integrated approaches for increasing water productivity in irrigated rice- based systems in Asia. Plant Prod. Sci. 8, 231-241.

Williams, P. N., Islam, M. R., Adomako, E. E., Raab, A., Hossain, S. A., Zhu, Y. G., Feldmann, J. and Meharg, A. A. (2006). Increase in rice grain arsenic for regions of Bangladesh irrigating paddies with elevated arsenic in ground waters. Environ. Sci. Technol. 40, 4903-4908.

\section{How to cite this article:}

Bairagya, M.D., C.K. Kundu and Sarkar, S. 2018. Mitigate Grain Arsenic Load of Summer Rice through Water Management. Int.J.Curr.Microbiol.App.Sci. 7(06): 572-577. doi: https://doi.org/10.20546/ijcmas.2018.706.065 